\title{
Contamination of a High-Cell-Density Continuous Bioreactor
}

\author{
Lucília Domingues, Nelson Lima, José A. Teixeira \\ Centro de Engenharia Biológica-IBQF, Universidade do Minho, 4710-057 \\ Braga, Portugal; telephone: 351-253-604400; fax: 351-253-678986; \\ e-mail: jateixeira@deb.uminho.pt
}

Received 2 May 1999; accepted 19 December 1999

\begin{abstract}
Continuous fermentations were carried out with a recombinant flocculent Saccharomyces cerevisiae strain in an airlift bioreactor. Once operating under steady state at a dilution rate of $0.45 \mathrm{~h}^{-1}$, the bioreactor was contaminated with Escherichia coli cells. The faster growing E. coli strain was washed out of the bioreactor and the recombinant, slower growing flocculating $S$. cerevisiae strain remained as the only species detected in the bioreactor. Flocculation, besides allowing for the realization of high-cell-density systems with corresponding unusual high productivity, may be used as a selective property for controlling some contamination problems associated with prolonged continuous operation. (c) 2000 John Wiley \& Sons, Inc. Biotechnol Bioeng 68: 584-587, 2000. Keywords: airlift bioreactor; continuous operation; flocculent $S$. cerevisiae; bacterial contamination
\end{abstract}

\section{INTRODUCTION}

Yeast flocculation can be described as the native and reversible aggregation of single cells into flocs of many thousands of cells. Microbial flocculation and aggregate formation are of particular importance in many industrial processes, such as brewing, biomass production, wastewater treatment, and bioconversion. For fermentors containing organisms in suspension, the association of single cells into flocs is a key factor in the overall process. The overall productivity is enhanced, because not only is a higher microbial hold-up in the fermentor obtained but also the separation of biomass from the fermented broth is facilitated. Moreover, it allows for continuous operation beyond the normal washout flow rate. A disadvantage of the high-celldensity continuous system is that overall rates of growth and metabolism are likely to be reduced as a result of diffusional limitations on the transfer of substrate, product, oxygen, and protons through the floc (Mozes and Rouxhet, 1990). One of the main disadvantages attributed to the continuous process, in general, is the risk of contamination with faster

Correspondence to: J. A. Teixeira

Contract grant sponsor: IBQF; FCT

Contract grant number: PRAXIS XXI/BD/11306/97 growing microorganisms and consequent takeover of the culture. This is a very important aspect of continuous recombinant cultures, as the cells that lose plasmid generally grow faster than the plasmid-containing ones (Davis and Parnham, 1989; Davison et al., 1985; Henry and Davis, 1990; Stephanopoulos et al., 1985; Walls and Gainer, 1989). In a competitive situation, the species with the fastest growth rate should do better, because, by virtue of its rapid growth, it will be able to utilize more of the limiting factor than the slower growing organism (Bailey and Ollis, 1986). However, in the context of microbial competition in open environments, a slower growing organism, if present in an ecologically advantageous niche, such as a film, has been observed experimentally to persist in competition with faster growing species (Bailey and Ollis, 1986). The concept of selective cell recycle for maintaining continuous fermentation with recombinant cultures stems from this principle and has been proposed by several investigators (Henry and Davis, 1990; Davis and Parnham, 1989; Davison et al., 1985; Stephanopoulos et al., 1985; Sheintuch, 1987). In this work, an airlift bioreactor operating at high cell density with flocculating recombinant yeast cells is shown to be resistant to contamination with a faster growing, undesired bacterial strain, thus supporting the argument of increased resistance to nonflocculent contaminants in the bioreactor operating at sufficiently high flow rates.

\section{MATERIALS AND METHODS}

\section{Strains and Media}

A flocculent recombinant Saccharomyces cerevisiae strain NCYC869-A3/T1 (Domingues et al., 1999a) was used for the continuous culture. The bacteria strain used as contaminant was Escherichia coli. Contamination experiments were also done with the E. coli HB101 purchased from Bio-Rad transformed with the pGLO plasmid (Bio-Rad), which encodes a gene for the green fluorescent protein (GFP) and a gene for resistance to ampicillin. The pGLO plasmid also incorporates motifs of the arabinose operon to regulate the 
expression of the protein. Therefore, in the presence of arabinose, recombinant cells fluoresce a brilliant green color as they produce more and more protein. In the absence of arabinose, the GFP protein is not expressed and the bacteria colonies exhibit a wild-type phenotype.

The continuous bioreactor was fed with SSLactose medium of the following composition: $\mathrm{KH}_{2} \mathrm{PO}_{4}, 5 \mathrm{~g} \mathrm{~L} \mathrm{~L}^{-1}$; $\left(\mathrm{NH}_{4}\right)_{2} \mathrm{SO}_{4}, 2 \mathrm{~g} \mathrm{~L}^{-1} ; \mathrm{MgSO}_{4} \cdot 7 \mathrm{H}_{2} \mathrm{O}, 0.4 \mathrm{~g} \mathrm{~L}^{-1}$; and yeast extract, $1 \mathrm{~g} \mathrm{~L}^{-1}$. The carbon source was $50 \mathrm{~g} \mathrm{~L}^{-1}$ lactose. For the contamination assays with the E. coli transformed with pGLO plasmid, the SSLactose medium was supplemented with $1 \mathrm{~g} \mathrm{~L}^{-1}$ casein and $100 \mu \mathrm{g} \mathrm{mL}^{-1}$ ampicillin.

\section{Batch Experiments}

Batch assays were performed in 500-mL Erlenmeyer flasks containing $200 \mathrm{~mL}$ of culture medium under 150-rpm agitation at $30^{\circ} \mathrm{C}$. Bacterial growth was followed by reading the optical density (OD) at $600 \mathrm{~nm}$.

\section{Continuous Experiments}

An airlift bioreactor with a Perspex concentric draft tube was used, which is shown schematically in Figure 1. Filtered air was injected immediately below the annulus of the riser, thus promoting an ejection effect responsible for circulation inside the reactor. At the top, the inverted conic enlargement provided a degassing area and floc deceleration zone. Part of the fermented liquid sheared off naturally and the remainder was recirculated along with biomass into the downcomer and again into the riser. A vertical barrier surrounded the outlet pool thus preventing the biomass particles from being driven off by the effluent. The working

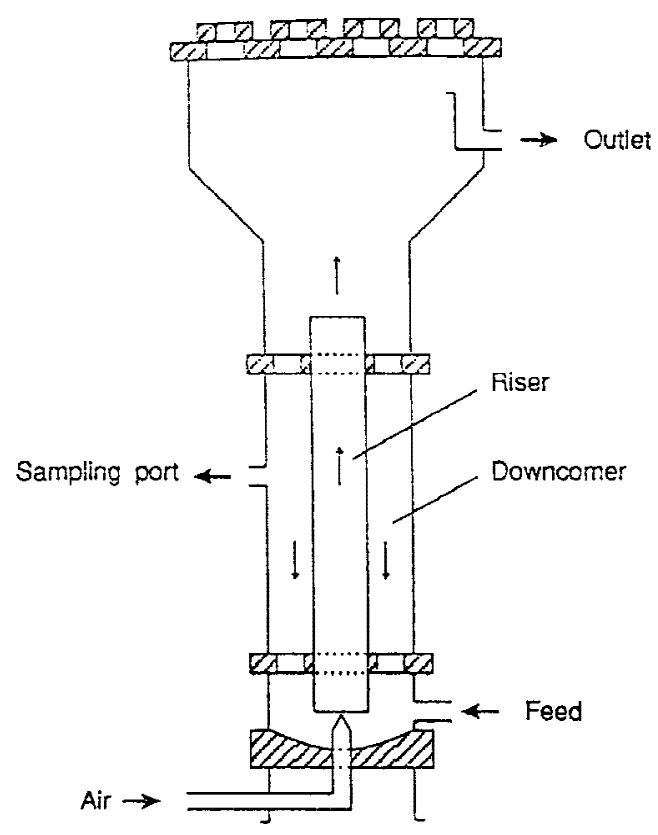

Figure 1. Schematic representation of the airlift bioreactor. volume was $5.5 \mathrm{~L}$ and the riser-downcomer diameter ratio was 0.46 . Fresh medium was fed at the bottom of the reactor. The regulation system allowed: temperature control at $30 \pm 1^{\circ} \mathrm{C}$; foam level control by addition of antifoam (Sigma A-5551); and pH control by automatic addition of ammonia, with the setpoint fixed at $\mathrm{pH} 4.0 \pm 0.1$. The system was aerated with filtered air at a rate of $1 \mathrm{vvm}$. The operating dilution rate was $0.45 \mathrm{~h}^{-1}$.

\section{Bacteria Cell Counting}

Colony plate counting was used to quantify bacterial concentration. Samples were taken from the bioreactor at defined timepoints and diluted and spread in Actidione Oxoid plates of the following composition: $4 \mathrm{~g} \mathrm{~L}^{-1}$ yeast extract, 5 $\mathrm{g} \mathrm{L}^{-1}$ tryptone, $50 \mathrm{~g} \mathrm{~L}^{-1}$ glucose, $0.55 \mathrm{~g} \mathrm{~L}^{-1} \mathrm{KH}_{2} \mathrm{PO}_{4}, 0.425$ $\mathrm{g} \mathrm{L}^{-1} \mathrm{KCl}, 0.125 \mathrm{~g} \mathrm{~L}^{-1} \mathrm{CaCl}_{2}, 0.125 \mathrm{~g} \mathrm{~L}^{-1} \mathrm{MgSO}_{4}, 0.0025$ $\mathrm{g} \mathrm{L}^{-1} \mathrm{FeCl}_{3}, 0.0025 \mathrm{~g} \mathrm{~L}^{-1} \mathrm{MnSO}_{4}, 0.01 \mathrm{~g} \mathrm{~L}^{-1}$ cycloheximide, $15 \mathrm{~g} \mathrm{~L}^{-1}$ agar, and $\mathrm{pH}$ adjusted to 5.5; or in LB plates of the following composition: $10 \mathrm{~g} \mathrm{~L}^{-1}$ casein, $5 \mathrm{~g} \mathrm{~L}^{-1}$ yeast extract, $5 \mathrm{~g} \mathrm{~L}^{-1} \mathrm{NaCl}, 15 \mathrm{~g} \mathrm{~L}^{-1}$ agar supplemented with 100 $\mu \mathrm{g} \mathrm{mL} \mathrm{m}^{-1}$ ampicillin, and $1 \mathrm{~g} \mathrm{~L}^{-1}$ arabinose.

\section{Yeast Cell Counting}

The $S$. cerevisiae cell concentration was estimated by counting cells in the Neubauer chamber after deflocculation with $15 \mathrm{~g} \mathrm{~L}^{-1} \mathrm{NaCl}(\mathrm{pH} 3.0)$ solution.

\section{RESULTS AND DISCUSSION}

The contaminant utilized was the bacteria Escherichia coli. In batch experiments in SSLactose medium at $30^{\circ} \mathrm{C}$, the maximum growth rate $\left(\mu_{\max }\right)$ for the strain indicated was found to be $0.59 \mathrm{~h}^{-1}$. This shows that, even under nonoptimal conditions, the $E$. coli strain was faster growing than the recombinant Saccharomyces cerevisiae strain, and thus, theoretically, the $E$. coli culture should overtake the yeast bioreactor culture at operating dilution rates $<0.59 \mathrm{~h}^{-1}$. Thus, contamination experiments were done in the continuous bioreactor operating at the dilution rate of $0.45 \mathrm{~h}^{-1}$ because, in a previous study (Domingues et al., 1999b), this was determined to be the maximum dilution rate allowing for stable operation of the bioreactor with the recombinant $S$. cerevisiae strain. In the first contamination assay, an initial concentration of $E$. coli in the bioreactor of $1 \times 10^{4}$ cells $\mathrm{mL}^{-1}$ was used. After $11 \mathrm{~h}$, only $2 \%$ of the initial contaminating inoculum was detected, whereas, after $24 \mathrm{~h}$, no contaminating bacteria were detected in the bioreactor. Moreover, the $S$. cerevisiae cell concentration inside the bioreactor remained unchanged. So far, Actidione Oxoid plates were used for determining $E$. coli concentration in this assay, because cycloheximide, at a concentration of $0.001 \% \mathrm{w} / \mathrm{v}$, permits growth of bacteria but inhibits the growth of $S$. cerevisiae. In this way, only bacterial colonies are formed. However, due to the high cell density 
inside the bioreactor $\left(50 \mathrm{~g} \mathrm{~L}^{-1}\right)$, a background was visible that made difficult to count the $E$. coli colonies. To overcome this difficulty, the following assays were made with $E$. coli strain HB101 transformed with pGLO plasmid. Using this system, LB plates supplemented with ampicillin and arabinose can be used for growth and counting of $E$. coli colonies. Because E. coli colonies fluoresce under ultraviolet light, the problem of background is overcome as the colonies are easily identified.

Prior to the contamination experiments with this genetically modified $E$. coli strain batch assays were made to test the conditions for growth. The E. coli HB101/pGLO recombinant strain was grown in SSLactose supplemented with ampicillin at different casein concentrations. With this experiment, it was observed that casein concentration was a growth-limiting nutrient. Although similar specific growth rates $\left(\mu_{\max }=0.60 \pm 0.08 \mathrm{~h}^{-1}\right)$ were obtained at different initial casein concentrations (no casein, $0.1 \mathrm{~g} \mathrm{~L}^{-1}, 0.5 \mathrm{~g} \mathrm{~L}^{-1}$, $1 \mathrm{~g} \mathrm{~L}^{-1}, 5 \mathrm{~g} \mathrm{~L}^{-1}$ ), growth was strongly limited for concentrations $<1 \mathrm{~g} \mathrm{~L}^{-1}$. In addition, batch experiments were made with simultaneous growth of bacteria and yeast in SSLactose medium supplemented with $1 \mathrm{~g} \mathrm{~L}^{-1}$ casein, and clearly showed that bacterial growth was not affected by the presence of yeast.

Using this strain, another contamination assay was made with a stronger inoculum of contaminant as the initial bacterial concentration in the bioreactor $\left(1 \times 10^{7}\right.$ cells $\left.\mathrm{mL}^{-1}\right)$. Figure 2 shows the variation in bacterial concentration inside the bioreactor over time. The bacterial concentration in the outlet stream was also estimated, overlapping with the results shown in Figure 2.

At the dilution rate of $0.45 \mathrm{~h}^{-1}$, after $4 \mathrm{~h}$ of operation, an accentuated decrease in contaminant concentration was observed in the bioreactor and in the effluent (Fig. 2). This extremely low value of contaminant concentration remained constant for the next $20 \mathrm{~h}$, clearly indicating that, at high dilution rates, bacterial contamination is not a problem for these bioreactors. However, as expected, if the dilution rate was lowered to significantly lower values, contamination would reappear.

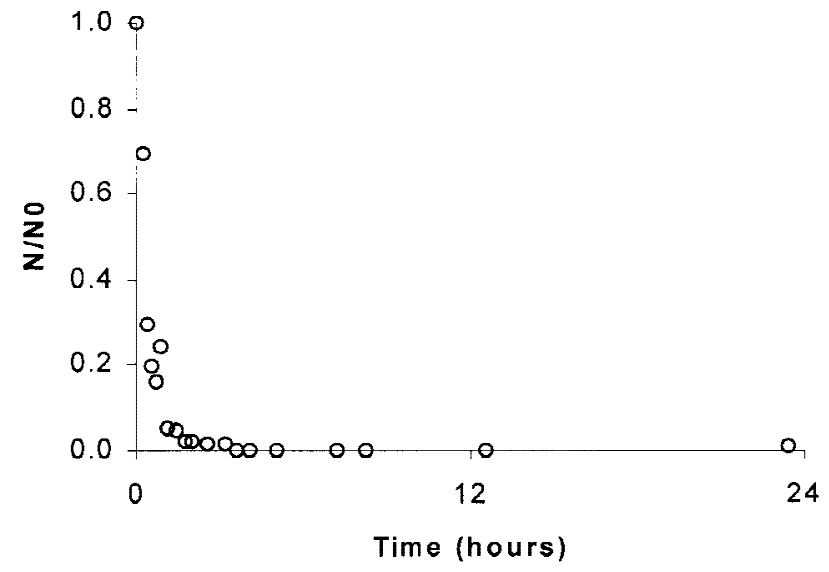

Figure 2. Time dependence of bacteria concentration inside the reactor; $\mathrm{N}$, bacterial concentration at time value $\mathrm{t} ; \mathrm{N}_{0}$, initial bacteria concentration.
Once the liquid phase volume hold-up of the airlift bioreactor, with a biomass concentration of $50 \mathrm{~g} \mathrm{~L}^{-1}$ (dry weight), was no more than $75 \%$ of the reactor volume, a higher operating dilution rate was obtained. As such, the operation was held at a dilution rate near the washout dilution rate of the bacteria, and higher than that of the recombinant $S$. cerevisiae strain. In spite of this, the yeast strain remained inside the bioreactor due to its ability of flocculate. In this way, other factors, besides strain interaction should be considered when analyzing systems operating with cells that have the ability to form aggregates. Among these, sedimentation characteristics are undoubtedly of particular importance and can be considered as an ecological advantage for the slower growing strain. The settling velocity of a particle is given by the Stokes law as:

$$
v_{s}=\frac{g D^{2}\left(\rho_{p}-\rho_{F}\right)}{18 \mu_{F}}
$$

where $\rho_{P}$ is the density of the particle, $\rho_{F}$ and $\mu_{F}$ are the density and viscosity of the fluid, respectively, $D$ is the diameter of the particle, and $g$ the acceleration of gravity. The velocity, $v_{s}$, usually, referred to as the Stokes velocity, is valid for a low particle concentration and a low Reynolds number. According to Eq. (1) one can estimate the Stokes velocity for different-sized particles, as shown in Table I.

The density difference between floc and liquid was found to be 0.1 by Lima et al. (1992). The diameter of the floc was estimated by image analysis (Vicente et al., 1996). As can be seen in Table I, the bacteria and yeast cells that do not flocculate show a very low Stokes velocity and are easily dragged off the bioreactor in the outlet. On the contrary, due to its high settling velocity, floc removal is prevented. Even so, it might be argued that the nonflocculent cells could be entrapped inside the flocs (Soares et al., 1992), thus being retained inside the bioreactor. However, once the contamination occurs with the bioreactor at steady state-that is, with the flocs well formed-the entrapment of nonflocculent cells will not be significant. In support of this, during one of the contamination assays, $1 \mathrm{~g} \mathrm{~L}^{-1}$ arabinose was added to the fermentation medium during the first hours of operation and epifluorescent microscopic observations of the flocs were done. No fluorescent bacteria were found inside the flocs, and only some cells adhering to the floc periphery were visible in the first hours after contamination.

The results described in this work demonstrate that an airlift bioreactor operating at high cell density with flocculent cells may be used to maintain a slower growing, but

Table I. Estimated Stokes velocity ( $\left.v_{\mathrm{s}}\right)$ for E. coli, S. cerevisiae, and floc of S. cerevisiae.

\begin{tabular}{lcc}
\hline \multicolumn{1}{c}{ Particle } & $D(\mathrm{~cm})$ & $v_{\mathrm{s}}\left(\mathrm{cm} \mathrm{s}^{-1}\right)$ \\
\hline E. coli cell & $0.1-5 \mathrm{E}-4$ & $5.4 \mathrm{E}-8-1.4 \mathrm{E}-4$ \\
S. cerevisiae cell & $10-50 \mathrm{E}-4$ & $5.4 \mathrm{E}-4-1.36 \mathrm{E}-2$ \\
S. cerevisiae floc & $0.1-0.2$ & $5.4-2.2 \mathrm{E} 1$ \\
\hline
\end{tabular}


flocculent, strain in a continuous operation when it would otherwise be washed out by a faster growing, nonflocculent contaminant. It is expected that these results may be useful in helping to maintain continuous fermentations with cultures (e.g., recombinant cultures) over prolonged time periods, especially in unclean environments, such as industrial settings. Moreover, this type of airlift bioreactor presents some advantages over the reactor-settler system, such as design simplicity and consequent easy scale-up. This work provides evidence of the advantages of high-cell-density continuous fermentation systems in overcoming contaminations.

\section{References}

Bailey JE, Ollis DF. 1986. Biochemical engineering fundamentals, 2nd ed. Singapore: McGraw-Hill. 984 p.

Davis RH, Parnham CS. 1989. Competitive yeast fermentation with selective flocculation and recycle. Biotechnol Bioeng 33:767-776.

Davison BH, San K-Y, Stephanopoulos G. 1985. Stable competitive coexistence in a continuous fermentor with size-selective properties. Biotechnol Prog 1:260-268.

Domingues L, Teixeira JA, Lima N. 1999a. Construction of a flocculent Saccharomyces cerevisiae fermenting lactose. Appl Microbiol Biotechnol 51:621-626.
Domingues L, Lima N, Teixeira JA. 1999b. Continuous ethanol fermentation of lactose by a recombinant flocculating Saccharomyces cerevisiae strain. Biotechnol Bioeng 64:692-697.

Henry KL, Davis RH. 1990. Continuous recombinant bacterial fermentations utilizing selective flocculation and recycle. Biotechnol Prog 6: $7-12$.

Lima N, Teixeira JA, Mota M. 1992. Enhancement of metabolic rates of yeast flocculent cells through the use of polymeric additives. Bioproc Eng 7:343-348.

Mozes N, Rouxhet PG. 1990. Microbial hydrophobicity and fermentation technology. In: Doyle RJ, Rosenberg M, editors. Microbial cell surface hydrophobicity. Washington, DC: American Society for Microbiology. p 75-105.

Sheintuch M. 1987. Species selection in a reactor-settler system. Biotechnol Bioeng 30:598-606.

Soares EV, Teixeira JA, Mota M. 1992. Interaction between flocculent and nonflocculent cells of Saccharomyces cerevisiae. Can J Microbiol 38: 969-974.

Stephanopoulos G, San K-Y, Davison BH. 1985. A novel bioreactor-cell precipitator combination for high-cell density, high-flow fermentations. Biotechnol Prog 1:250-259.

Vicente A, Meinders JM, Teixeira JA. 1996. Sizing and counting of Saccharomyces cerevisiae floc populations by image analysis, using an automatically calculated threshold. Biotechnol Bioeng 51:673-678.

Walls EL, Gainer JL. 1989. Retention of plasmid bearing cells by immobilisation. Biotechnol Bioeng 34:717-724. 